\title{
Historical Mata Volcano Boninites and Primary Magma Musings
}

\author{
KENNETH H RUBIN ${ }^{1}$, ERIC HELLEBRAND ${ }^{2}$, SARAH \\ GLANCY $^{3}$ AND PETER J MICHAEL ${ }^{4}$
}

${ }^{1}$ University of Hawaii at Manoa

${ }^{2}$ Utrecht University

${ }^{3}$ UH Manoa

${ }^{4}$ University of Tulsa

Presenting Author: krubin@hawaii.edu

Boninite is a mafic to ultramafic "high-Mg andesite" magma type with exceptionally high $\mathrm{Si}$ and low $\mathrm{Ti}$ as measured in the whole rock [1]. Since $2 \mathrm{Ga}$ in the rock record it is mostly associated with subduction zone settings [2]. Submarine West Mata volcano in the NE Lau Basin (Tonga) represents Earth's only known Historical location of Boninite Volcanism [3]. It and 8 nearby small submarine volcanoes of the Mata Group, which have also exclusively erupted pristine, geologically modern Boninite lavas, provide an excellent location with which to study the compositional, mineralogical, textural, and geochemical characteristics of this magma type. The whole rock compositional extreme of Mata Boninite extends to $\mathrm{MgO} 20$ $\mathrm{wt} \%, \mathrm{SiO}_{2} 57 \mathrm{wt} \%$ and $\mathrm{Ti}_{2} \mathrm{O} 0.3 \mathrm{wt} \%$, although the rocks populate a fairly wide array of the $\mathrm{Si}-\mathrm{Mg}$-Ti chemical definition space between oxide values (given as $\% \mathrm{MgO}, \mathrm{SiO}_{2}, \mathrm{Ti}_{2} \mathrm{O}$ ) of 20 , $51,0.5$ to $8.5,58,0.4$ to $18,54.5,0.3$. As a group they make trends that extend outside of the Boninite definition sensu-strictu, perhaps from mixing with non-Boninite parent magmas, potentially complicating the extent to which their trace element compositions can be related unequivocally to mantle wedge and introduced fluid sources of specifically boninite parentage, as is commonly done.

Mata Boninites tend to be highly crystal rich (25-40\%), with far less extreme co-existing glass compositions, most commonly in the range of 8-12 $\mathrm{wt} \% \mathrm{MgO}, 56-57 \mathrm{wt} \% \mathrm{SiO}_{2}$ and $0.3-0.4 \mathrm{wt} \%$ $\mathrm{Ti}_{2} \mathrm{O}$. Variations in Mata Boninite crystal size, morphology and composition determined by electron microprobe indicate primarily but not exclusively normally-zoned phenocrystic assemblages of multiple morphological growth populations (e.g., incipient, mature), with significant compositional variation, perhaps including accumulation of antecrystic and even xenocrystic populations. The compositional complications of these visually beautiful rocks and implications for petrogenesis will be discussed along with ample images of rock compositions and textures.

[1] Le-Bas, M.J. (2000) J. Petrol. 41, 1467-1470 (2000); [2] Pearce, J.A.\& Reagan, M.K. (2019) Geosphere 15, 1008-1037; [3] Resing. J. et al. (2011) Nature Geosci. 4, 799-806 